\title{
Epidemiology, diagnosis, treatment, and future perspectives concerning SARS-COV-2: a review article
}

Arthur Ricardo Vilar Scavuzzi de Carvalho

(iD) Murilo Lobo Cezarotti Filho ${ }^{1}$

Dedro Cavalcanti Pires de Azevedo ${ }^{1}$

(iD) Robson Natario Silveira Filho ${ }^{1}$

(D) Fabiano Timbó Barbosa $a^{\mathbf{1 2 , 3}}$

(iD) Thiago José Matos Rocha,

(D) Célio Fernando de Sousa-Rodrigues,

(iD) Fernando Wagner da Silva Ramos ${ }^{1,4,5}$

1. Centro Universitário Cesmac, Maceió, AL, Brasil. 2. Universidade Federal de Alagoas - UFAL, Maceió, AL, Brasil. 3. Hospital Geral do Estado de Alagoas - HGE, Maceió, AL, Brasil. 4. Secretaria de Estado da Saúde de Alagoas - SESAU, Maceió, AL, Brasil. 5. Universidade Estadual de Ciências da Saúde de Alagoas - UNCISAL, Maceió, AL, Brasil.

http://dx.doi.org/10.1590/1806-9282.66.3.370

\section{SUMMARY}

The present study aimed to review the epidemiology, clinical manifestation, laboratory diagnosis, treatment, and future perspectives related to COVID-19 infections. The following electronic databases were used searched: MEDLINE, SCIELO, and LILACS. It became clear that COVID-19 infections occur through exposure to the virus, and both the immunosuppressed and healthy population appear susceptible. The clinical course of COVID-19 is still not clear, although the SARS-CoV-2 infection seems to develop with mild, influenza-like symptoms in the vast majority of subjects, i.e., 10\%-15\% of COVID-19 patients. Since rRT-PCR tests serve as the gold standard method to confirm a SARS-CoV-2 infection, false-negative results could hinder the prevention and control of the epidemic, particularly considering the test plays a key role in the decision for continued isolated medical observation or discharge. Our findings also indicate that a radical increase in the identification and isolation of currently undocumented infections would be needed to fully control SARS-CoV2.

KEYWORDS: Coronavirus. Epidemiology. Signs and symptoms. Diagnosis. Therapeutics.

\section{INTRODUCTION}

The coronavirus was initially designated as the 2019-novel coronavirus (2019-nCoV) in January 2020 by the World Health Organization (WHO). The disease caused by it was named coronavirus disease 2019 (COVID-19). The Coronavirus Study Group of the International Committee suggested naming the new coronavirus as SARS-CoV-2, based on taxonomy, phylogeny, and established practice issued in February 2020'. In December 2019, several acute respiratory illnesses, now called COVID-19, occurred in Wuhan, Hubei Province, China. A total of 3,588,773 cases of COVID-19 have been confirmed including 247,503 
deaths as of May 06 2020. The pathogen of this disease was confirmed as a novel coronavirus by molecular methods, and to date, COVID-19 has affected people in more than 189 countries and has become a global pandemic ${ }^{2}$.

Coronaviruses are enveloped single-stranded RNA viruses that are zoonotic in nature and cause symptoms ranging from those similar to the common cold to more severe respiratory, hepatic, enteric asymptomatic carrier, pneumonia of varying degrees of severity and neurological symptoms $\mathbf{3}^{3,4}$.

There are relevant factors associated with COVID19; therefore, the present study aimed to review the epidemiology, clinical manifestation, laboratory diagnosis, treatment, and future perspectives related to the COVID-19 infection epidemiology.

\section{METHODS}

The following electronic databases were included in this review: Medical Literature Analysis and Retrieval System Online (MEDLINE) via PubMed (1966 to January 2020), available through the following link: https:// www.ncbi.nlm.nih.gov/pubmed/; Scientific Electronic Library Online (SCIELO), available at https://www.scielo.org/ and Literatura Latino-Americana e do Caribe em Ciências da Saúde (LILACS), available through the following link: https://bvsalud.org/; (1982 to January 2020). The electronic search resulted in 908 articles. Among them, thirteen were duplicates. After selecting the title and abstract, 74 articles were identified for a complete evaluation of the text. From those, 24 were used for the final review. There was no date and language restriction. Records were managed by EndNote X 9.0 software.

\section{Epidemiology}

It became evident that the COVID-19 infection occurs through exposure to coronavirus, and both the immunosuppressed and healthy population appear to be susceptible. Some studies have documented an age distribution of adult patients between 25 and 89 years old. Most adult patients were between 35 and 55 years old 5 . A study on early transmission dynamics of the virus reported the average age of patients to be 59 years old, ranging from 15 to 89 years, with the majority (59\%) being male. It was suggested that the population most at risk might be people with a poor immune function, such as older people and those with renal and hepatic dysfunction ${ }^{6}$.

Figure 1 shows the number of confirmed COVID-19 cases reported by country, territory or area, 30 April to 6 May, in accordance with WHO.

The epidemic of unknown acute respiratory tract

FIGURE 1. NUMBER OF CONFIRMED COVID-19 CASES REPORTED BY COUNTRY, TERRITORY OR AREA, 30 APRIL TO 6 MAY, 2020, IN ACCORDANCE WITH WHO.

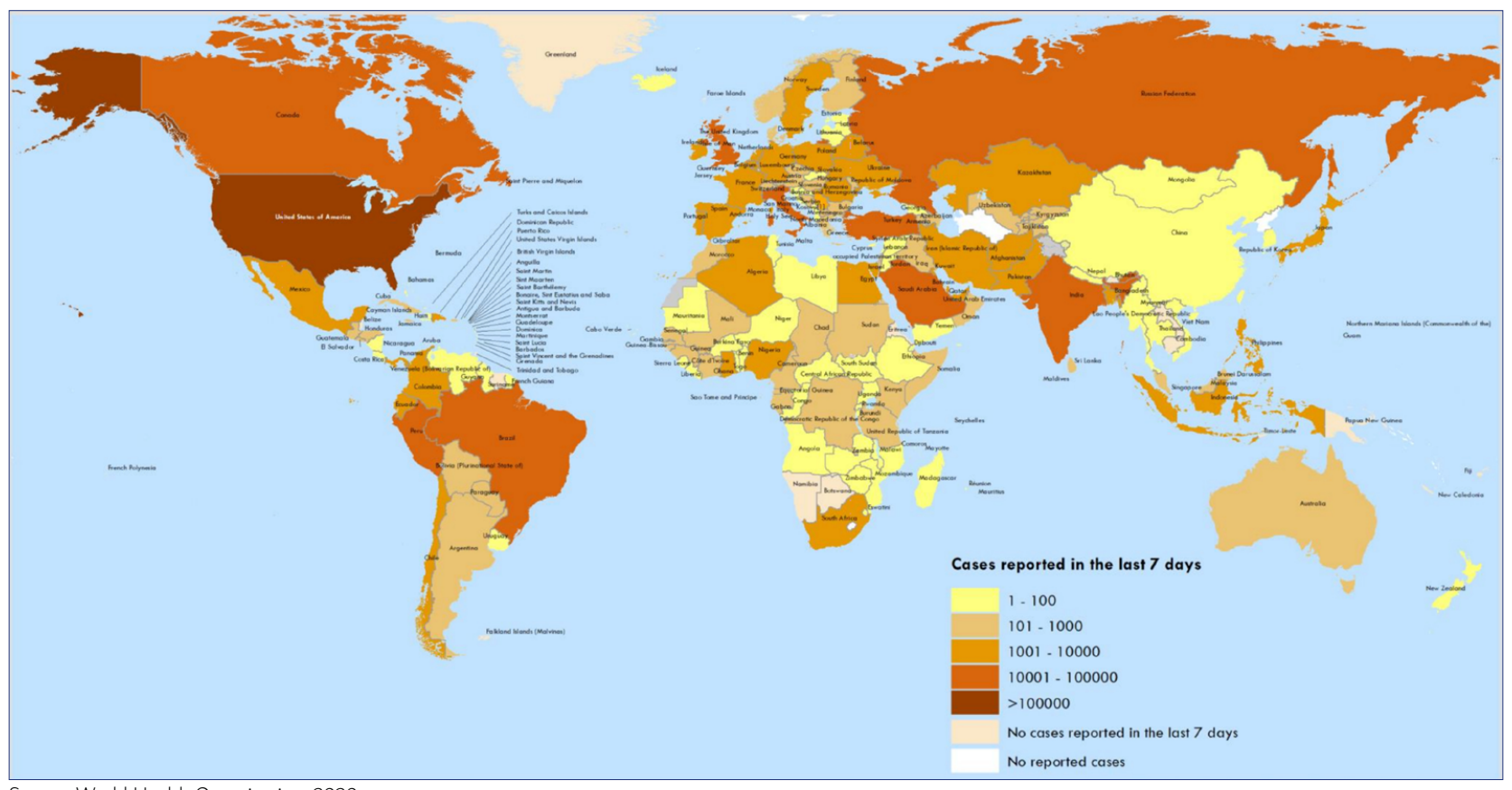

Source: World Health Organization, 2020 
infections broke out first in Wuhan, China, in December 2019. This is possibly linked to the seafood market. Several studies suggested that bats may be the potential source of SARS-CoV-2. However, there is no evidence to date that the origin of SARS-CoV-2 is from the seafood market ${ }^{7}$.

Currently, person to person transmission from patients with pneumonia or asymptomatic patients during the incubation period is the main source for the spread of the virus. Respiratory droplets are the main route of transmission, but the virus can also be transmitted through interpersonal contact or through the fecal-oral route based on a study that demonstrates the presence of the virus in rectal swabs ${ }^{8,9}$. Prevention and control strategies and methods are reported at three levels: national level, case-related population level, and general population level ${ }^{10}$.

Airborne precautions and other protective measures have been discussed and proposed for prevention. Infection preventive and control measures that may reduce the risk of exposure include the following: use of face masks; covering coughs and sneezes with tissues that are then safely discarded ${ }^{11}$.

Presently, there are four endemic coronavirus strains currently circulating in human populations: 229E, HKU1, NL63, OC43. If the novel coronavirus follows the pattern of the $2009 \mathrm{H} 1 \mathrm{~N} 1$ pandemic influenza, it will also spread globally and become a fifth coronavirus pandemic in the human population ${ }^{12}$. Table 1 shows data as reported by national authorities on 6 May 2020.

TABLE 1. DATA AS REPORTED BY NATIONAL AUTHORITIES ABOUT SARS-COV-2 ON 6 MAY 2020

$\begin{array}{lll} & \text { Confirmed } & \text { Deaths } \\ \text { Western Pacific Region } & 154884 & 6327 \\ \text { European Region } & 1593828 & 147780 \\ \text { South-East Asia Region } & 76998 & 2821 \\ \text { Eastern Mediterranean Region } & 221230 & 8290 \\ \text { Region of the Americas } & 1507148 & 81070 \\ \text { African Region } & 33973 & 1202 \\ \text { Globally } & 3588773 & 247503 \\ \text { Source: World Health Organization, 2020 } & \end{array}$

\section{Clinical manifestation}

The clinical course of COVID-19 is still unclear. Although the SARS-CoV-2 infection seems to occur with mild, influenza-like symptoms in the vast majority of subjects, i.e., $10 \%-15 \%$ of COVID-19 patients (especially older ones and those with relevant comorbidities), the disease may progress to severe interstitial pneumonia, which may then evolve to acute respiratory distress syndrome and death in $2 \%-5 \%$ of cases $^{13}$.

Reliable evidence suggests that the incubation period of SARS-CoV-2 is approximately 6 days and that the average period between symptom onset and hospitalization is 7 days, while the average period of symptom duration is approximately 13 days, or slightly longer in patients with severe disease (16 days $)^{14}$.

In a study involving 108 patients (38 men, 70 women; age range, 21-90 years old), the manifestations observed were fever in 94 of 108 patients (87\%), dry cough in 65 of 108 (60\%), and fatigue in 42 of 108 (39\%). The laboratory results were normal white blood cells (WBC) count in 97 of 108 patients (90\%) and normal or reduced lymphocyte count in 65 of 108 (60\%). High-sensitivity C-reactive protein level was elevated in 107 of 108 patients (99\%). Most patients have lymphopenia and bilateral ground-glass opacity changes on chest computed tomography (CT) scans ${ }^{15}$.

\section{Laboratorial diagnosis}

The nucleic acid test or genetic sequencing for SARSCoV-2 was considered the gold standard method for confirmation of infection. Since rRT-PCR tests serve as the gold standard method to confirm a SARS-CoV-2 infection, false-negative results could hinder the prevention and control of the pandemic, especially since the test plays a key role in the decision for the need of continued isolated medical observation or discharge. The accuracy of RT-PCR can be substantially affected by the lack of harmonization of primers and probes, as well as by a variety of technical and analytical errors ${ }^{16}$.

Studies on COVID-19 have generally been limited to the description of the epidemiology characteristics, initial clinical, hematological, and radiological findings. Laboratory results also found that SARS-CoV-2 is similar to some of the beta $(\beta)$ coronaviruses generally identified in bats ${ }^{17}$, which are part of a group of SARS/ SARS-like CoV viruses. Case definition guidelines mention the following symptoms: decreased lymphocytes and white blood cells, new pulmonary infiltrates on chest radiography, and lack of improvement of symptoms after 3 days of antibiotic treatment ${ }^{6}$. For patients with a suspected infection, the following procedures have been suggested for diagnosis: real-time fluorescence RT-PCR to detect the positive nucleic acid of SARS-CoV-2 in sputum, throat swabs, and secretions of the lower respiratory tract samples ${ }^{18}$. 
In the advanced phase of SARS-CoV infection, rapid reduction of lymphocytes in peripheral blood, mainly T lymphocytes, was observed, and both CD4 and CD8 $\mathrm{T}$ lymphocytes decreased. The loss of lymphocytes precedes even the abnormal changes on the chest X-ray. SARS-specific IgG antibodies are produced in the late advanced stages (about 2 weeks) and gradually increase with the course of the disease. The sustainable existence of IgG makes the patients acquire immune function after the infection. The IgG level of mild patients was significantly higher than that of severely infected patients ${ }^{19}$.

\section{Treatment and futures perspectives}

Suspected and confirmed cases need to be treated in designated hospitals under effective quarantine conditions. Suspected cases need to be treated separately in a single room, with confirmed cases admitted to the same ward, and critical cases should be admitted to ICU as soon as possible ${ }^{20}$.

Unfortunately, there is no known specific treatment against COVID-19. Because of this, identifying effective antiviral agents to combat the disease is urgently necessary. However, chloroquine phosphate has shown apparent effectiveness in the treatment of COVID-19 associated pneumonia in clinical studies. Chloroquine is a 9-aminoquinoline discovered in 1934; it is used to prevent and treat malaria and is effective as an anti-inflammatory agent for the treatment of rheumatoid arthritis and lupus erythematosus. The drug also has many interesting biochemical properties, including an antiviral effect. Studies revealed that it also has potential against viral infection. Moreover, chloroquine was also found to be a potent inhibitor of SARS coronavirus infection by interfering with ACE2, one of cell surface binding sites for S protein of SARS-CoV ${ }^{21}$.

The development of attenuated-virus vaccines is also possible by carefully screening the serially propagated SARS-CoV-2 with reduced pathogenesis such as induced minimal lung injury, diminished limited neutrophil influx, and increased anti-inflammatory cytokine expressions compared with the wild-type virus ${ }^{22}$.

At least five vaccine technologies will be reviewed: inactivated vaccine, subunit protein vaccine, nucleic acid vaccine, adenoviral vector vaccine, and recombinant influenza viral vector vaccine ${ }^{23}$. Traditional vaccine technologies have been improved, and a wide variety of new technologies have emerged in the past two decades ${ }^{24}$.

\section{CONCLUSION}

Our findings also indicate that a radical increase in the identification and isolation of currently undocumented infections would be necessary to control SARS-CoV2 fully. An estimation of the prevalence and contagiousness of undocumented novel coronavirus (SARS-CoV2) infections is critical for understanding the overall prevalence and pandemic potential of this disease. These findings explain the rapid geographic spread of SARS-CoV2 and indicate containment of this virus will be particularly challenging. No specific antiviral treatments or vaccines are available because it is a new and emerging viral disease. The development of SARS-CoV-2-based vaccines is urgently required.

\section{Conflicts of interest}

The authors declare there are no conflicts of interest that may have influenced this work.

\section{Authors' contributions}

ARVSC, MLCF, PCPA, and RNSF searched the databases. TJMR, CFSR, FTB, and FWSR selected the articles to be included in the research. FWSR corrected the writing in English. All authors performed the other parts of the research in an equally. All authors have reviewed and approved the final text of this article and are responsible for its content.

\section{RESUMO}

O presente estudo teve como objetivo realizar uma revisão sobre epidemiologia, manifestações clínicas, diagnóstico laboratorial, tratamento e perspectivas futuras relacionados à infecção pelo COVID-19. As seguintes bases de dados eletrônicas foram utilizadas MED LINE, SCIELO e LILACS. Ficou claro que a infecção pelo COVID-19 ocorre por exposição ao vírus, e tanto a população imunossupressora quanto a normal parecem suscetíveis. O curso clínico do COVID-19 ainda não está claro, embora a infecção por SARS-CoV-2 pareça ocorrer com sintomas leves e semelhantes à gripe na grande maioria dos indivíduos, em 10\%-15\% dos pacientes com COVID-19. Uma vez que os testes rRT-PCR servem como o método padrão-ouro para confirmar a infecção do SARS-CoV-2, os resultados falso-negativos podem dificultar a prevenção e o controle da epidemia, particularmente quando este teste desempenha um papel de referência fundamental na decisão da necessidade de observação médica isolada ou alta. Nossos achados também indicam que seria necessário um aumento radical na identificação e isolamento de infecções não documentadas atualmente para controlar totalmente o SARS-CoV2. 


\section{REFERENCES}

1. Lu R, Zhao X, Li J, Niu P, Yang B, Wu H, et al. Genomic characterisation and epidemiology of 2019 novel coronavirus: implications for virus origins and receptor binding. Lancet. 2020;395(10224):565-74.

2. World Health Organization. Coronavirus disease (COVID-2019) situation reports Geneva: World Health Organization; 2020. [cited 2020 March 20]. Available from: https://www.who.int/emergencies/diseases/novel-coronavirus-2019/ situation-reports

3. Zhu N, Zhang D, Wang W, Li X, Yang B, Song |, et al. A novel coronavirus from patients with pneumonia in China, 2019. N Engl J Med. 2020;382(8):727-33.

4. Zaki $A M, \operatorname{Van}$ Boheemen $S$, Bestebroer $T M$, Osterhaus $A D$, Fouchier RA. Isolation of a novel coronavirus from a man with pneumonia in Saudi Arabia. N Engl ] Med. 2012;367(19):1814-20.

5. Medical expert group of Tongji hospital. Quick guide to the diagnosis and treatment of pneumonia for novel coronavirus infections. 3rd ed. Herald Med. 2020. [cited 2020 Feb 2]. Available from: http://kns.cnki.net/kcms/detail/42.12 93.r.20200130.1803.002.htm

6. Li Q, Guan X, Wu P, Wang X, Zhou L, Tong Y, et al. Early transmission dynamics in Wuhan, China, of novel coronavirus-infected pneumonia. N Engl | Med. 2020;382(13):1199-207.

7. Giovanetti M, Benvenuto D, Angeletti S, Ciccozzi M. The first two cases of 2019nCoV in Italy: where they come from? J Med Virol. 2020;92(5):518-21.

8. Rothe C, Schunk M, Sothmann P, Bretzel G, Froeschl G, Wallrauch C, et al. Transmission of 2019-nCoV infection from an asymptomatic contact in Germany. N Engl | Med. 2020;382(10):970-71.

9. American College of Obstetricians and Gynecologists' Editorial Board for Clinical Updates in Women's Health Care. Clinical updates in women's health care summary: liver disease: reproductive considerations. Obstet Gynecol. 2017;129(1):236.

10. National Health Commission of People's Republic of China. Pneumonia infected with novel coronavirus is included in the management of legal infectious diseases. 2020. [cited 2020 March 20]. Available from: http://www.nhc.gov.cn/jkj/ s7915/202001/e4e2d5e6f01147e0a8df3f6701d49f33.shtml

11. United States of America. Centers for Disease Control and Prevention. 2019 Novel coronavirus, Wuhan, China. 2020. [cited 2020 March 20]. Available from: https://www.cdc.gov/coronavirus/2019-nCoV/summary.html

12. Li R, Pei S, Chen B, Song Y, Zhang T, Yang W, et al. Substantial undocumented infection facilitates the rapid dissemination of novel coronavirus (SARS-CoV2). Science 10.1126/science.abb3221. 2020. [cited 2020 March 20]. Available from: https://science.sciencemag.org/content/early/2020/03/24/science.abb3221/ tab-pdf
13. World Health Organization. Coronavirus disease 2019 (COVID-19) Situation Report - 48. Geneva: World Health Organization; 2020. [cited 2020 March 9]. Available from: https://.www.who.int/emergencies/diseases/ novel-coronavirus-2019/situation-reports/

14. Young BE, Ong SWX, Kalimuddin S, Low IG, Tan SY, Loh |, et al. Epidemiologic features and clinical course of patients infected with SARS-CoV-2 in Singapore. JAMA. 2020 Mar 3. doi: 10.1001/jama.2020.3204.

15. Huang C, Wang Y, Li X, Ren L, Zhao J, Hu Y, et al. Clinical features of patients infected with 2019 novel coronavirus in Wuhan, China. Lancet. 2020;395(10223):497-506.

16. Van Zyl G, Maritz |, Newman H, Preiser W. Lessons in diagnostic virology: expected and unexpected sources of error. Rev Med Virol. 2019;29(4):e2052.

17. Gang L, Chen MJ, Chen W. Variation in the titer of the specific IgG antibody in patients with SARS. I Trop Med. 2003;3:283-5.

18. Li T, Wei C, Li W, Hongwei F, Shi J. Beijing Union Medical College Hospital on "pneumonia of novel coronavirus infection" diagnosis and treatment proposal (V2.0). Med I Peking Union Med Coll Hosp. 2020. [cited 2020 March 9]. Available from: http://kns.cnki.net/kcms/detail/11.5882.r.20200130.1430.002.html

19. Cao Z, Liu L, Du L, Zhang C, Jiang S, Li T, et al. Potent and persistent antibody responses against the receptor-binding domain of SARS-CoV spike protein in recovered patients. Virol J. 2010;7:299.

20. Jin $Y H$, Cai L, Cheng ZS, Cheng H, Deng T, Fan YP, Fang C, et al. A rapid advice guideline for the diagnosis and treatment of 2019 novel coronavirus (2019-nCoV) infected pneumonia (standard version). Mil Med Res. 2020;7(1):4.

21. Vincent MJ, Bergeron E, Benjannet S, Erickson BR, Rollin PE, Ksiazek TG, et al. Chloroquine is a potent inhibitor of SARS coronavirus infection and spread. Virol J. 2005;2:69.

22. Regla-Nava JA, Nieto-Torres JL, Jimenez-Guardeño JM, Fernandez-Delgado R, Fett C, Castaño-Rodríguez $C$, et al. Severe acute respiratory syndrome coronaviruses with mutations in the $\mathrm{E}$ protein are attenuated and promising vaccine candidates. J Virol. 2015;89(7):3870-87.

23. Lu S. Timely development of vaccines against SARS-CoV-2. Emerg Microbes Infect. 2020;9(1):542-4

24. Lu S. Editorial overview: vaccines against challenging viral pathogens and new vaccine technology. Curr Opin Virol. 2014;6:viii-ix. 